\title{
Evaluation of Customer Satisfaction about the Provided Services by EGYPTAIR Tourism and Duty Free
}

\author{
Doaa Yousry mahmoud \\ Amany El-Shahat Ibrahim \\ Faculty of Tourism and \\ Hotels, Minia University \\ Prof. Tourism Studies Department \\ Faculty of Tourism and Hotels, \\ Helwan University \\ Hussein AbdEl-wahab Abd El-Rady \\ Assist Prof. Tourist Studies \\ Department Faculty of Tourism \\ and Hotels, Minia University
}

\section{$\underline{\text { Abstract }}$}

The success of airlines depends majorly on the ability to identify customer perception, expectation to achieve customer satisfaction. This paper aims to assess the quality of service provided by EGYPTAIR tourism and duty-free and its impact on customer satisfaction. To achieve that, this research employed a method of descriptive-analytical methodology by using an e- questionnaire tool. The sample was customers in EGYPTAIR tourism and duty-free. 255 questionnaires were administered; only (228) returned questionnaires were valid for the statistical manipulation of data with a response rate of $89.5 \%$ from the total distributed questionnaires in social media. The results of the tools were analyzed using descriptive statistics, reliability analysis, coefficient analysis, Spearman correlation analysis, and regression analysis with the support of SPSS v.22.

The research reached several results, Findings of this study revealed that all five dimensions of the SERVQUAL scale i.e. Tangibility, Reliability, Responsiveness, Assurance, and Empathy have a positive, direct and significant impact on customer satisfaction of EGYPTAIR tourism and duty-free. The results of the study indicated a strong positive correlation between the dimensions of service quality (tangible, reliability, responsiveness, assurance and empathy) and customer satisfaction. It can be concluded from this that EGYPTAIR tourism's customer satisfaction can be increased by improving the service quality of all its dimensions. It is expected that findings of this study will help airlines to understand the role of 
various dimensions of service quality for enhancing their customer satisfaction. The research thus recommended Egypt Air Tourism \& Duty-Free should develop its services with high quality at a reasonable price to help EGYPTAIR Tourism and Duty-free to compete and maintain customers.

Keywords: Customer Loyalty, Customer Satisfaction, EGYPTAIR Tourism and Duty Free, Service Quality,SERVQUAL.

\section{Introduction}

Service quality is an important subject in both the public and private sectors, in business and service industries (Zahari et al., 2008).globalization and stiff competition have changed the landscape of doing business. A decrease in customer satisfaction and an increase in customer expectations have challenged businesses to come up with unparalleled methods of enhancing their quality of service. The same is true for airline industry too. As a result, many airlines have changed their marketing strategies, especially with regard to service quality, in order to compete efficiently in the global market (Mishal, 2015). the service quality is considered as a critical dimension of competitiveness and providing excellent service quality and high customer satisfaction is the important issue and challenge facing the contemporary service industry (baker, 2012) and has strong impact on business performance, lower costs, return on investment, customer satisfaction, customer loyalty and gaining higher profit (baker, 2012).

In the airline industry, service quality is a great competitive advantage for airlines profitability. Passengers are the most important factor in this industry because airlines depend on their passengers therefore, companies have to understand the passenger's needs and want to deliver great experiences and high-quality service (Kim and lee, 2011). delivering high-quality service to customers is the key strategy to survive in today"s competitive service industries such as airline transportation services (Kenan \& Yildirim, 2012). further, Saha and theingi (2009), zeithamal, berry and prasuraman (1996), and namukasa (2013) found that service quality played a significant role in determining customer satisfaction, and helping a company to achieve a good position in the airlines industry. Then, company should pay more attention to building an adorable image to its customers. 
Roy(2015) suggests that managers can choose approach according to the industry settings as many dimensions for measuring service quality are available in the literature.Some of airlines are assigned to a department or workgroup, whose mission is to provide tourism services to passengers on their flights, from the organization of tourism programs of various types: from hospital, sea trips, shopping, or trips for newlyweds and other tourism programs that attract wide sectors of Tourists, and meet the needs of their customers. For example, EGYPTAIR Tourism and Duty-Free of EGYPTAIR Holding Company, which carries out tourism programs with all related services (Haza,2011).

EGYPTAIR tourism \& duty-free is one of EGYPTAIR's subsidiaries, in 24/12/2009, a decision was made by the president of the general authority for investment and free zones no. 21/g of 2009 issued for licensing EGYPTAIR tourism "Karnak" and duty-free company to operate the free zones activity subject to provisions of law no. 8 of 1997 (EGYPTAIR annual report 20162017).EGYPTAIR tourism ( Karnak ) \& duty-free is comprised of two separate business sectors: duty-free: provides duty-free retail services to passengers at nine major airport locations throughout the country as the largest duty-free retailer in Egypt. Karnak tourism services provides inbound and outbound touristic/conferencing services and operates a fleet of passenger vehicles of varying sizes specifically for tourism (EGYPTAIR, 2019).

\section{Literature review Service Quality}

An initial conceptualisation of service quality was discussed by Parasuraman et al. (1985) as a function of the difference between service expectations and customers' perceptions of the actual service delivered. They suggested that customers perceive the relative quality of services by comparison the actual performance of the firm with their own expectations, shaped by experience, word of mouth communications, and/or memories (Tsoukatos and Mastrojianni, 2010); this comparison is referred to as perceived service quality (Parasuraman et al., 1988). Service quality can therefore be defined as the difference between customers' expectations of service and perceived service. If expectations are greater than performance, then perceived quality is less than satisfactory and hence customer discontentment happens (Parasuraman et al., 1985; Lewis, 2010). 


\section{SERVQUAL Model}

Several conceptual models have been developed by different researchers for measuring service quality. It is envisaged that conceptual models in service quality enable management to identify quality problems and thus help in planning for the launch of a quality improvement program thereby improving the efficiency, profitability and overall performance (Seth and Deshmukh, 2005).Service quality measurement is based on the SERVQUAL Gap modelwhich is an instrument used for measuring customers' perception of service quality proposed by Parasuraman et al. (1988). The purpose of SERVQUAL is to explain the gap that occurs between consumer expectations and what they actually receive. This gap represents service quality and is a function of perceptions minus expectations.

\section{$\underline{\text { Customer Satisfaction }}$}

Customer satisfaction is one of the best-studied marketing fields, because it has become a principal factor in achieving organizational goals, and is regarded to be a basic standard of performance and a necessary standard of excellence for any organization (Gerson, 1993; Munusamy and Chelliah, 2011). Several studies have concluded that it is more costly to gain a new customer than it does to retain an existing one Blodgett et al.,(1995). Furthermore, Sousa and Voss (2009) found that customer satisfaction is distinctly linked to customer loyalty, Higher customer satisfaction leads to higher customer loyalty and reduced customer satisfaction leads to reduced customer loyalty.

As it impacts future consumer purchasing behavior, profitability and shareholder value (Chitty, Ward, \& Chua,2007).In addition, customer satisfaction leads to favorable word-of-mouth, which offers a valuable form of indirect advertising to the organization (Park et al., 2005). The literature demonstrates that customer satisfaction is important to get long-term company Moreover, several studies generally define customer satisfaction and dissatisfaction as the customer's judgments concerning a company's success or failure in meeting expectations (Chidambaram,\& Ramachandran, 2012). 
The Relationship Between The Service Quality And The Customer Loyalty

According to Falk, Hammerschmidt, and Schepers (2010), the effect of the service quality on the customer loyalty is in two forms: a direct influence and an indirect influence through customer satisfaction, or a moderating effect through satisfaction. As far as the direct effect is concerned,Boshoff and Gray (2004) have demonstrated that the service quality is an antecedent to customer loyalty. Likewise, many studies in different industries have also revealed a positive relationship between service quality and customer satisfaction, as well as the tendency of repeated purchase (Chen, Chen, \& Hsieh, 2007; He \& Song, 2009).Zineldin (2006) contends that businesses should view the quality as a product and service bundle. Hence, when business organizations provide a high level of product or service, the level of customers' satisfaction increases, as well as the loyalty status, while some studies reported that the service quality accounted for significant variation in the customer loyalty (Oliver, 1997; Rahim, 2015). Some scholars maintain that uncertainty surrounds the service quality and the loyalty relationship since some studies have failed to discover a significant link between the two constructs (Roberts, Varki, \& Brodie, 2003; Egan, 2004).Customer satisfaction is also likely to impact on loyalty. Hu et al. (2009) and Jen et al. (2011) observe that satisfied customers tend to be loyal, reflected by favorable behavioral intention. Jaiswal and Niraj (2011) and Yuksel et al. (2010) illustrate that customer satisfaction significantly and positively affects customer loyalty.To a large number of scholars, the loyalty relates to intention or disposition (Ahmad, 2007). In the opinion of Seth and Sobel (2001; cited in Silvia, Pedro, Vitor, \& Jael, 2013), customer loyalty can be demonstrated through loyalty behavior and attitudes. According to these scholars, there is loyalty behavior when the consumer repurchases, which shows that the customer is pleased with the product. On the other hand, the loyalty attitude occurs when the consumer's motivation to buy an frm's product is accessibility or force of habit; and such a consumer is interested in the relationship sustenance that can stand the competitive enticement.

EGYPTAIR TOURISM ( KARNAK ) \& DUTY FREE

EGYPTAIR Tourism (Karnak ) \& Duty Free is Comprised Of Two Separate Business Sectors: 
EGYPTAIR DUTY FREE:

Offers the traditional duty free items with a large range of international brands. We also establish, manage and organize free Shops in ports, airports, tourist groups and Egyptian aircraft inside and outside the republic. ( EGYPTAIR Annual Report , 20162017).Duty free shops are located in the following airports: Cairo, Alexandria, SharmEl Sheik, Hurghada, Luxor, Marsa Alam, Taba, Sohaj and Aswan.

There are six non airport shops located in CityStars/Cairo, Soho Square

/ Sharm El Sheik, Port Ghalib / Marsa Alam, El Gouna / Hurghada, Hilton Hotel / Taba and El Manfaz El Nahry /Aswan 2010-2011 ( EGYPTAIR Annual Report , 2010/2011).

\section{EGYPTAIR (Karnak):}

Karnak Tourism Services: offers inbound and outbound touristic/conference services and operates a fleet of passenger vehicles of varying sizes specifically for tourism (karnak, 2019 ).Karnak is one of the most experienced companies in the field of Travel and Tourism in Egypt and the Middle East.Karnak was established in 1955 under license number 6, category (A) and is the tourism sector of Egypt air which is one of the subsidiaries of Egypt air Holding Company, a Star Alliance Member.Karnak has around 10 sales offices all over Egypt with 300 skilled employees to provide a variety of services to meet customers' expectations. (karnak, 2019 ).The main core of the Sector is to promote the numbers of tourists by marketing programs internally and externally,through the tools that we have to serve the needs of tourism (EGYPTAIR Annual Report 2016/2017).

Tourism division offers airline ticket sales, domestic tourism, tourist transportation, religious tours ( Hajj \& Umrah) and outgoing tour packages for Egyptians and residents.Also Karnak offers online hotel booking, agreements are signed with "Destination of the World", "GTA" and Thomas Cook to make use their hotel booking systems affording hotel booking for the customers of Karnak.Karnak has wide experience in handling conferences, exhibitions and special events.Karnak has a 24 hours transit offce at Cairo International Airport to provide a meeting \& assistance service and arrange quick tours to transit passengers.Karnak has contracted agreements 
permitting the issue of web based insurance policies which are used to facilitate visa procedures for Egyptian travellers (EGYPTAIR Annual Report 2010/2011).

\section{Methodology}

The researcher used the descriptive analytical approach, where a questionnaire was prepared and distributed to a random sample of two hundred and Fifty-five(255) of customers in EGYPTAIR tourism and duty-free. 228 ( $89.5 \%$ ) of customers in EGYPTAIR tourism and dutyfreewere retrieved. The statistical analysis of the responses was carried out via SPSS v.22

\section{$\underline{\text { Data Collection }}$}

Data has been collected through questionnaires that were prepared in approach that is relevant to the situation so as to decrease invalid responses. They were distributed to customers in EGYPTAIR TOURISM AND DUTY FREE.

\section{Measures}

This research's purpose is Measuring the services quality that provided by EGYPTAIR Tourism and Duty-Free and its impact on customer satisfaction. To achieve that, this research employed a method of descriptive-analytical methodology by using a questionnaire tool, a survey consisted of FIVE sections was used as a data collection tool. The first section includes the demographic characteristics of respondents (gender, age group, educational level, income, purpose of trip and frequency). The second section included the evaluation of the services quality provided by EgyptAir Tourism and Duty-Free. The third section included the evaluation of the Customer Satisfaction EgyptAir Tourism and Duty-Free. The fourth section included the evaluation of the customer loyalty EgyptAir Tourism and Duty-Free. The fifth section of the questionnaire combination of closed-ended and open-ended questions to Evaluation of Customer Satisfaction.

The questionnaire items were anchored according to the Five Point Likert Scale, "1 = Strongly Disagree (SD)", "2 = Disagree (D)", "3 = Neutral (N)", "4 = Agree (A)", and "5= Strongly Agree (SA)".

\section{Data Validity and Reliability}

\section{Data Validity}


To validate the data collection instrument utilized in this study in terms of its readability, format, and ability to measure the study's constructs; the researchers distributed the questionnaire instrument to experts in Information and communication technologies and Academic experts in the tourism sector. The questionnaire instrument was then updated and refined to reflect the comments and suggestions received by the domain experts. Moreover, the experts showed interest and interacted with the researchers concerning the questionnaire instrument which adds to its validity.

\section{Data Reliability}

The reliability of an instrument is the degree of accuracy and consistency with that it measures whatever it is measuring (Ary et al., 2002). Before proceeding with further analysis, the reliability test was done in order to ensure consistent measurement across various items in the questionnaire. As depicted in table ( 6 ), the Cronbach's Alpha Reliability was computed. The tests showed that the Reliability Coefficients for all the sections were equal .996 and Validity Coefficient for all the sections were equal .997 which indicates that the instrument is reliable for being used.

Table 1: Cronbach's Alpha Value measuring for service quality and customer satisfaction

\begin{tabular}{|l|c|l|l|}
\hline Variables & No. of items & $\begin{array}{l}\text { Cronbach's Alpha } \\
\text { Value }\end{array}$ & $\begin{array}{l}\text { Validity } \\
\text { Coefficient } \\
*\end{array}$ \\
\hline $\begin{array}{l}\text { Service Quality } \\
\text { (Tangibility- Reliability- Responsiveness- Assurance- Empathy) }\end{array}$ \\
\hline Hajj \& Omrah & 23 & .980 & .989 \\
\hline Domestic Tours & 23 & .990 & .994 \\
\hline Outgoing Tours & 23 & .928 & .963 \\
\hline Transit servicing & 23 & .990 & .994 \\
\hline Mice & 23 & .925 & .961 \\
\hline Transportation services & 23 & .984 & .991 \\
\hline Online booking service & 23 & .897 & .947 \\
\hline Duty free & 23 & .906 & .951 \\
\hline Customer satisfaction & 36 & .991 & .995 \\
\hline loyalty & 9 & .916 & .957 \\
\hline total & $\mathbf{2 2 9}$ & $\mathbf{9 9 6}$ & .997 \\
\hline
\end{tabular}

* Validity coefficient $=\sqrt{ }$ Reliability coefficient 
Minia Journal of Tourism and Hospitality Research Vol. (8), No. (1), December 2019

In order to measure the internal consistency and reliability of the study's constructs. Cronbach's Alpha $(\alpha)$ measure was used. The scales' reliabilities were measured and the Cronbach's Alpha of all scales in Table ( 1 ) ranged from .980 to .916, and for total questionnaire items was (.996), this indicate an acceptable Cronbach's Alpha value for each field, whenever Cronbach's Alpha value is acceptable if it's more than (0.7). It is also evident that the validity coefficient is $(99.7 \%)$ which means the reliability and validity of the study sample. 
Minia Journal of Tourism and Hospitality Research Vol. (8), No. (1), December 2019

Findings and Discussion

First Section: Demographic characteristics of respondents

$53 \%$ of the respondents were male whereas $47 \%$ of them were female. Most of the respondents $44.7 \%$ were aged between 18 and 28 years. Regarding the education level, $68 \%$ of the respondents were studying for Bachelor's degrees. Additionally, more than 35.5 $\%$ of the respondents reported an income range between 3.000and 5.999 EGP. Regarding the purpose of their journeys, about $86.8 \%$ mentioned that they were traveling for Entertainment / Vacation.the majority (54.4\%) of the sample travel for a purpose Tourist programs inside Egypt By Egypt Air Tourism \& Duty-Free, (50\%) of the sample travel from 1 to 2 by Egypt Air Tourism \& Duty-Free in the past 12 months, whereas (78.5\%)of the sample use Company website to get information about EGYPTAIR Tourism and DutyFree.

Second Section: measuring service quality of EGYPTAIR Tourism \& Dutv-Free services

Table(2) EGYPTAIR Tourism \& Duty-Free services

\begin{tabular}{|c|c|c|c|c|}
\hline \multirow{2}{*}{ Variable } & \multicolumn{2}{|c|}{ Frequency } & \multicolumn{2}{|c|}{$\begin{array}{c}\text { Percentage } \\
(\%)\end{array}$} \\
\hline & Yes & no & yes & no \\
\hline \multicolumn{5}{|c|}{ What services did you use by EGYPTAIR Tourism \& Duty-Free Shops } \\
\hline Hajj \& Omrah & 114 & 144 & 50.0 & 50.0 \\
\hline Domestic Tours & 124 & 104 & 54.4 & 45.6 \\
\hline Outgoing Tours & 109 & 119 & 47.8 & 52.2 \\
\hline Transit & 65 & 163 & 28.5 & 71.5 \\
\hline Meetings \& conferences organizing service & 61 & 167 & 26.8 & 73.2 \\
\hline Transportation services & 60 & 168 & 26.3 & 73.7 \\
\hline Online booking services & 63 & 165 & 27.6 & 72.4 \\
\hline Duty-Free & 71 & 157 & 31.1 & 68.9 \\
\hline
\end{tabular}

Table (2) show that the majority $(54.4 \%)$ of the sample travel for a purpose Domestic Tours By Egypt Air Tourism \& Duty Free, whereas(50.0)\% of the sample travel for a purpose Hajj and omrah.

- Domestic Tours

Table (3) Tangibility dimension of Domestic Tours 
Minia Journal of Tourism and Hospitality Research Vol. (8), No. (1), December 2019

\begin{tabular}{|l|l|l|l|l|l|l|l|l|l|}
\hline \multicolumn{1}{|c|}{ Variables } & SD & D & N & A & SA & Mean & $\begin{array}{l}\text { Standard } \\
\text { deviation }\end{array}$ & Rank & Attitude \\
\hline 1. Tangibility a & & & & & & High \\
\hline $\begin{array}{l}\text { The devices and } \\
\text { equipment used to } \\
\text { perform the service } \\
\text { are modern and } \\
\text { advanced }\end{array}$ & 2.2 & 2.2 & 18.4 & 21.1 & 10.1 & 3.64 & 0.968 & 2 & High \\
\hline $\begin{array}{l}\text { The appearance of } \\
\text { the service staff is } \\
\text { elegant and neat }\end{array}$ & 1.8 & 2.6 & 16.7 & 21.1 & 11.4 & 3.70 & 0.968 & 1 & \\
\hline Total mean
\end{tabular}

Table (3) presents the means and standard deviations of Tourist Programs Inside Egypt that provided by EGYPTAIR Tourism \& Duty Free.The above table shows the responses of the study sample that related to the Tangibility dimension, where the means ranged between (3.70-3.64) compared with the total instrument mean for the domain (3.67) the item "The appearance of the service staff is elegant and neat" ranked first with a mean and standard deviation (mean $=3.70$, standard deviation $=0.968$ ) compared with the total instrument mean and the standard deviation. The item "The devices and equipment used to perform the service are modern and advanced" ranked last reached a mean (3.64) and the standard deviation was (0.968) compared with the mean and standard deviation of the total instrument. 
Minia Journal of Tourism and Hospitality Research Vol. (8), No. (1), December 2019

Table (4) Reliability dimension of Domestic Tours

\begin{tabular}{|c|c|c|c|c|c|c|c|c|c|}
\hline Variables & SD & $\mathbf{D}$ & $\mathbf{N}$ & $\mathbf{A}$ & $\mathbf{S A}$ & Mean & $\begin{array}{c}\text { Standar } \\
\mathbf{d} \\
\text { deviatio } \\
\mathbf{n}\end{array}$ & Rank & Attitude \\
\hline \multicolumn{10}{|l|}{ 2. Reliability } \\
\hline $\begin{array}{l}\text { EGYPTAIR Tourism is } \\
\text { implementing its services } \\
\text { from the first time }\end{array}$ & 1.8 & 3.9 & 18.4 & 19.3 & 9.6 & 3.59 & 0.980 & 4 & High \\
\hline $\begin{array}{l}\text { EGYPTAIR Tourism } \\
\text { executes its services at } \\
\text { the exact time. }\end{array}$ & 1.3 & 3.5 & 16.2 & 20.6 & 11.8 & 3.71 & 0.966 & 1 & High \\
\hline $\begin{array}{l}\text { The services provided } \\
\text { by EGYPTAIR Tourism } \\
\text { are of good -quality and } \\
\text { meet the needs of } \\
\text { customers }\end{array}$ & 1.8 & 2.2 & 18.9 & 20.2 & 10.5 & 3.66 & 0.950 & 3 & High \\
\hline $\begin{array}{l}\text { When Customer faces a } \\
\text { problem, EGYPTAIR } \\
\text { Tourism shows a sincere } \\
\text { interest in solving it. }\end{array}$ & 1.3 & 3.5 & 17.5 & 21.1 & 10.1 & 3.66 & 0.943 & 2 & High \\
\hline \multicolumn{6}{|l|}{ Total mean } & 3.65 & & & \\
\hline
\end{tabular}

Table (4) shows the responses of the study sample to the paragraphs related to the Reliability dimension, where the means ranged between (3.71-3.59) compared with the total instrument mean for the domain (3.65) the item "EGYPTAIR Tourism executes its services at the exact time." ranked first with a mean and standard deviation (mean $=3.71$, standard deviation $=0.966$ ) compared with the total instrument mean and the standard deviation. The item "EGYPTAIR Tourism is implementing its services from the first time" ranked last reached a mean (3.59) and the standard deviation was (0.980) compared with the mean and standard deviation of the total instrument. 
Minia Journal of Tourism and Hospitality Research Vol. (8), No. (1), December 2019

Table (5) Responsiveness dimension of Domestic Tours

\begin{tabular}{|l|c|c|c|c|c|c|c|c|c|l|}
\hline \multicolumn{1}{|c|}{ Variables } & SD & D & N & A & SA & Mean & $\begin{array}{c}\text { Standard } \\
\text { deviation }\end{array}$ & Rank & Attitude \\
\hline 3. Responsiveness & 1.8 & 3.1 & 17.5 & 22.4 & 8.8 & 3.62 & 0.939 & 3 & High \\
\hline $\begin{array}{l}\text { EGYPTAIR Tourism staff } \\
\text { renders quick and } \\
\text { immediate services to } \\
\text { Customers }\end{array}$ & 1.8 & 3.9 & 17.5 & 19.7 & 10.5 & 3.62 & 0.990 & 4 & High \\
\hline $\begin{array}{l}\text { Quick response to } \\
\text { complaints and problems } \\
\text { solving }\end{array}$ & 1.8 & 3.9 & 19.3 & 18.0 & 10.5 & 3.59 & .994 & 5 & High \\
\hline $\begin{array}{l}\text { The waiting period for } \\
\text { rendering the service is } \\
\text { short }\end{array}$ & 1.3 & 2.6 & 18.4 & 21.5 & 9.6 & 3.66 & 0.915 & 2 & High \\
\hline $\begin{array}{l}\text { EGYPTAIR Tourism staff } \\
\text { are ready to help you }\end{array}$ & & & & & & & & & & \\
\hline $\begin{array}{l}\text { EGYPTAIR Tourism } \\
\text { Employee Makes } \\
\text { information easily } \\
\text { available for Customers }\end{array}$ & 2.6 & 3.1 & 13.6 & 22.8 & 11.4 & 3.70 & 1.028 & 1 & High \\
\hline \begin{tabular}{l} 
Total mean \\
\hline
\end{tabular} & & & & $\mathbf{3 . 6 3}$ & & & \\
\hline
\end{tabular}

Table (5) shows the responses of the study sample that related to the Responsiveness dimension, where the means ranged between (3.70-3.59) compared with the total instrument mean for the domain (3.63) the item "EGYPTAIR Tourism Employee Makes information easily available for Customers" ranked first with a mean and standard deviation (mean $=3.70$, standard deviation $=1.028)$ compared with the total instrument mean and the standard deviation. The item "The waiting period for rendering the service is short" ranked last reached a mean (3.59) and the standard deviation was (.994) compared with the mean and standard deviation of the total instrument. 
Minia Journal of Tourism and Hospitality Research Vol. (8), No. (1), December 2019

Table (6) Assurance dimension of Domestic Tours

\begin{tabular}{|l|l|l|l|l|l|l|l|l|l|l|}
\hline \multicolumn{1}{|c|}{ Variables } & SD & D & N & A & SA & Mean & $\begin{array}{l}\text { Standard } \\
\text { deviation }\end{array}$ & Rank & Attitude \\
\hline \multicolumn{2}{|l|}{ 4. Assurance } & & & & & & & & \\
\hline $\begin{array}{l}\text { EGYPTAIR Tourism staff } \\
\text { give accurate answers to } \\
\text { your questions }\end{array}$ & 1.8 & 3.1 & 17.5 & 19.7 & 11.4 & 3.67 & 0.983 & 5 & High \\
\hline $\begin{array}{l}\text { The staff's conduct instills } \\
\text { trust in Customers }\end{array}$ & 2.2 & 2.2 & 14.0 & 24.6 & 10.5 & 3.73 & 0.962 & 2 & High \\
\hline $\begin{array}{l}\text { EGYPTAIR Tourism } \\
\text { employees are always } \\
\text { committed with you }\end{array}$ & 1.8 & 2.6 & 19.3 & 20.2 & 9.6 & 3.62 & 0.948 & 6 & High \\
\hline $\begin{array}{l}\text { EGYPTAIR Tourism \& } \\
\text { Duty-Free has agood } \\
\text { reputation and image }\end{array}$ & 2.2 & 3.9 & 11.8 & 25.9 & 9.6 & 3.69 & 0.988 & 4 & High \\
\hline $\begin{array}{l}\text { You feel safe in your } \\
\text { dealings with EGYPTAIR } \\
\text { Tourism }\end{array}$ & 2.2 & 2.6 & 13.6 & 23.7 & 11.4 & 3.74 & 0.986 & 1 & High \\
\hline $\begin{array}{l}\text { EGYPTAIR Tourism staff } \\
\text { are experienced and well- } \\
\text { trained. }\end{array}$ & 1.8 & 2.6 & 15.4 & 23.7 & 10.1 & 3.70 & 0.942 & 3 & High \\
\hline \begin{tabular}{l} 
Total mean \\
\hline
\end{tabular}
\end{tabular}

Table(6) shows the responses of the study sample thatrelated to the Assurance dimension, where the means ranged between (3.743.62) compared with the total instrument mean for the domain (3.69) the item "You feel safe in your dealings with EGYPTAIR Tourism" ranked first with a mean and standard deviation (mean=3.74, standard deviation $=0.986$ ) compared with the total instrument mean and the standard deviation. The item "EGYPTAIR Tourism employees are always committed with you" ranked last reached a mean (3.62) and the standard deviation was (0.948) compared with the mean and standard deviation of the total instrument. 
Minia Journal of Tourism and Hospitality Research Vol. (8), No. (1), December 2019

Table(7 ) Empathy dimension of Domestic Tours

\begin{tabular}{|l|l|l|l|l|l|l|l|l|l|l|}
\hline \multicolumn{1}{|c|}{ Variables } & SD & D & N & A & SA & Mean & $\begin{array}{l}\text { Standard } \\
\text { deviation }\end{array}$ & Rank & Attitude \\
\hline \multicolumn{2}{|l|}{ 5. Empathy } \\
\hline $\begin{array}{l}\text { EGYPTAIR Tourism staff } \\
\text { have gaven you individual } \\
\text { attention }\end{array}$ & 1.8 & 2.6 & 18.4 & 21.5 & 9.2 & 3.63 & 0.938 & 2 & High \\
\hline $\begin{array}{l}\text { EGYPTAIR Tourism staff } \\
\text { understands your specific } \\
\text { needs }\end{array}$ & 2.2 & 3.9 & 14.5 & 24.1 & 8.8 & 3.62 & 0.982 & 3 & High \\
\hline $\begin{array}{l}\text { EGYPTAIR Tourism takes } \\
\text { consumer's opinions } \\
\text { seriously }\end{array}$ & 1.8 & 2.6 & 17.1 & 22.8 & 9.2 & 3.66 & 0.934 & 1 & High \\
\hline $\begin{array}{l}\text { Passengers are sufficiently } \\
\text { compensated by the airline } \\
\text { for any damages that arise in } \\
\text { the shortest possible time }\end{array}$ & 3.1 & 3.1 & 15.4 & 22.4 & 9.6 & 3.61 & 1.033 & 4 & High \\
\hline $\begin{array}{l}\text { EGYPTAIR Tourism staff } \\
\text { are show Empathy }\end{array}$ & 2.2 & 2.2 & 18.4 & 22.4 & 8.3 & 3.61 & 0.941 & 5 & High \\
\hline $\begin{array}{l}\text { EGYPTAIR Tourism staff } \\
\text { provides personal care } \\
\text { equally to everyone. }\end{array}$ & 2.6 & 3.5 & 16.7 & 21.1 & 9.6 & 3.59 & 1.018 & 6 & High \\
\hline \begin{tabular}{l} 
Total mean \\
\hline
\end{tabular}
\end{tabular}

Table(7) shows the responses of the study sample thatrelated to the Empathy dimension ,where the means ranged between (3.663.59) compared with the total instrument mean for the domain (3.62) the item "EGYPTAIR Tourism takes consumer's opinions seriously" ranked first with a mean and standard deviation (mean $=3.66$, standard deviation $=0.934$ ) compared with the total instrument mean and the standard deviation. The item "EGYPTAIR Tourism staff provides personal care equally to everyone" ranked last reached a mean (3.59) and the standard deviation was (1.018) compared with the mean and standard deviation of the total instrument. 
Minia Journal of Tourism and Hospitality Research Vol. (8), No. (1), December 2019

- Haji and omrah

Table (8) Tangibility dimension of Hajj and omrah

\begin{tabular}{|l|c|c|c|c|c|c|c|c|c|}
\hline \multicolumn{1}{|c|}{ Variables } & SD & D & N & A & SA & Mean & $\begin{array}{c}\text { Standard } \\
\text { deviation }\end{array}$ & Rank & Attitude \\
\hline 1. Tangibility \\
$\begin{array}{l}\text { The devices and } \\
\text { equipment used to } \\
\text { perform the service } \\
\text { are moder and } \\
\text { advanced }\end{array}$ & 0 & 3.1 & 17.1 & 22.4 & 7.0 & 3.67 & 0.796 & 2 & High \\
$\begin{array}{l}\text { The appearance of } \\
\text { the service staff is } \\
\text { elegant and neat }\end{array}$ & 2.6 & 1.3 & 10.5 & 25.4 & 9.6 & 3.77 & 0.973 & 1 & High \\
\hline \\
Total mean
\end{tabular}

Table (8) presents the means and standard deviations of Hajj and omrah that provided by EGYPTAIR Tourism \& Duty -Free, The above table shows the answers of the study sample that related to the Tangibility dimension, where the means ranged between (3.77- 3.67) compared with the total instrument mean for the field (3.72) the item"The appearance of the service staff is elegant and neat" ranked first with a mean and standard deviation (mean $=3.77$, standard deviation $=0.973$ ) compared with the total instrument mean and the standard deviation. The item "The devices and equipment used to perform the service are modern and advanced" ranked last reached a mean (3.67) and the standard deviation was (0.796) compared with the mean and standard deviation of the total instrument. 
Minia Journal of Tourism and Hospitality Research Vol. (8), No. (1), December 2019

\begin{tabular}{|l|c|c|c|c|c|c|c|c|c|c|}
\hline \multicolumn{1}{|c|}{ Variables } & SD & D & N & A & SA & Mean & $\begin{array}{c}\text { Standar } \\
\text { deviatio } \\
\text { n }\end{array}$ & Rank & $\begin{array}{c}\text { Attitu } \\
\text { de }\end{array}$ \\
\hline 2. Reliability & & & & & & & & & \\
\hline $\begin{array}{l}\text { EGYPTAIR Tourism is } \\
\text { implementing its services } \\
\text { from the first time. }\end{array}$ & .4 & 3.9 & 17.5 & 20.2 & 7.5 & 3.61 & 0.870 & 1 & High \\
\hline $\begin{array}{l}\text { EGYPTAIR Tourism } \\
\text { executes its services at the } \\
\text { exact time. }\end{array}$ & 1.8 & 4.4 & 14.9 & 21.9 & 6.6 & 3.55 & 0.954 & 2 & High \\
\hline $\begin{array}{l}\text { The services provided by } \\
\text { EGYPTAIR Tourism are } \\
\text { of good -quality and meet } \\
\text { the needs of customers }\end{array}$ & 1.8 & 4.8 & 15.8 & 21.5 & 5.7 & 3.50 & 0.946 & 4 & High \\
\hline $\begin{array}{l}\text { When Customer faces a } \\
\text { problem, EGYPTAIR } \\
\text { Tourism shows a sincere } \\
\text { interest in solving it. }\end{array}$ & 1.8 & 4.8 & 14.9 & 23.2 & 4.8 & 3.50 & 0.927 & 3 & High \\
\hline Total mean & & & & & & & & \\
\hline
\end{tabular}

Table (9) Reliability dimension of Hajj and omrah

Table (9) shows the responses of the study sample that related to the Reliability dimension, where the means ranged between (3.61- 3.50) compared with the total instrument mean for the domain (3.54) the item "EGYPTAIR Tourism is implementing its services from the first time" ranked first with a mean and standard deviation (mean=3.61, standard deviation $=0.870$ ) compared with the total instrument mean and the standard deviation. The item "The services provided by EGYPTAIR Tourism are of good -quality and meet the needs of customers" ranked last reached a mean (3.50) and the standard deviation was (0.946) compared with the mean and standard deviation of the total instrument. 
Minia Journal of Tourism and Hospitality Research Vol. (8), No. (1), December 2019

Table (10) Responsiveness dimension of Hajj and omrah

\begin{tabular}{|c|c|c|c|c|c|c|c|c|c|}
\hline Variables & SD & D & $\mathbf{N}$ & $\mathbf{A}$ & $\begin{array}{l}\mathbf{S} \\
\mathbf{A}\end{array}$ & $\begin{array}{c}\text { Mea } \\
\text { n }\end{array}$ & $\begin{array}{c}\text { Stand } \\
\text { ard } \\
\text { deviat } \\
\text { ion }\end{array}$ & Rank & $\begin{array}{c}\text { Attitu } \\
\text { de }\end{array}$ \\
\hline \multicolumn{10}{|l|}{ 3. Responsiveness } \\
\hline $\begin{array}{l}\text { EGYPTAIR } \\
\text { Tourism staff } \\
\text { renders quick and } \\
\text { immediate } \\
\text { services } \\
\text { Customers }\end{array}$ & .4 & 4.8 & $\begin{array}{c}15 . \\
8\end{array}$ & $\begin{array}{c}22 . \\
8\end{array}$ & $\begin{array}{l}5 . \\
7\end{array}$ & 3.58 & 0.854 & 3 & High \\
\hline $\begin{array}{l}\text { Quick response to } \\
\text { complaints and } \\
\text { problems solving }\end{array}$ & 3.1 & 5.3 & $\begin{array}{c}15 . \\
4\end{array}$ & $\begin{array}{c}20 . \\
6\end{array}$ & $\begin{array}{l}5 . \\
3\end{array}$ & 3.40 & 1.022 & 5 & High \\
\hline $\begin{array}{l}\text { The waiting period } \\
\text { for rendering the } \\
\text { service is short }\end{array}$ & .4 & 6.1 & $\begin{array}{c}18 . \\
9\end{array}$ & $\begin{array}{c}18 . \\
4\end{array}$ & $\begin{array}{l}5 . \\
7\end{array}$ & 3.46 & 0.887 & 4 & High \\
\hline $\begin{array}{l}\text { EGYPTAIR } \\
\text { Tourism staff are } \\
\text { ready to help you }\end{array}$ & 1.3 & 3.1 & $\begin{array}{c}12 . \\
3\end{array}$ & $\begin{array}{c}25 . \\
0\end{array}$ & $\begin{array}{l}7 . \\
9\end{array}$ & 3.71 & 0.903 & 1 & High \\
\hline $\begin{array}{l}\text { EGYPTAIR } \\
\text { Tourism } \\
\text { Employee Makes } \\
\text { information easily } \\
\text { available for } \\
\text { Customers }\end{array}$ & .9 & 3.9 & $\begin{array}{c}15 . \\
8\end{array}$ & $\begin{array}{c}22 \\
4\end{array}$ & $\begin{array}{l}6 . \\
6\end{array}$ & 3.60 & 0.882 & 2 & High \\
\hline Total mean & & & & & & 3.55 & & & \\
\hline
\end{tabular}

Table (10) shows the responses of the study sample that related to the Responsiveness dimension, where the means ranged between (3.713.40) compared with the total instrument mean for the domain (3.55) the item "EGYPTAIR Tourism staff are ready to help you" ranked first with a mean and standard deviation (mean=3.71, standard deviation $=0.903$ ) compared with the total instrument mean and the standard deviation. The item "Quick response to complaints and problems solving" ranked last reached a mean (3.40) and the standard deviation was (1.022) compared with the mean and standard deviation of the total instrument. 
Minia Journal of Tourism and Hospitality Research Vol. (8), No. (1), December 2019

Table (11) Assurance dimension of Hajj and omrah

\begin{tabular}{|l|l|l|l|l|l|l|l|l|l|l|}
\hline \multicolumn{1}{|c|}{ Variables } & SD & D & N & A & SA & Mean & $\begin{array}{c}\text { Standard } \\
\text { deviation }\end{array}$ & $\begin{array}{c}\text { Ran } \\
\text { k }\end{array}$ & Attitude \\
\hline \multicolumn{2}{|l|}{ 4. Assurance } & & & & & & & & \\
\hline $\begin{array}{l}\text { EGYPTAIR Tourism } \\
\text { staff give accurate } \\
\text { answers to your } \\
\text { questions }\end{array}$ & 1.3 & 3.5 & 15.4 & 22.4 & 7.0 & 3.61 & 0.911 & 5 & High \\
\hline $\begin{array}{l}\text { The staff's conduct } \\
\text { instills trust in } \\
\text { Customers }\end{array}$ & 0 & 4.4 & 14.0 & 25.4 & 5.7 & 3.65 & 0.799 & 3 & High \\
\hline $\begin{array}{l}\text { EGYPTAIR Tourism } \\
\text { employees are always } \\
\text { committed with you }\end{array}$ & .9 & 3.9 & 15.4 & 23.2 & 6.1 & 3.60 & 0.872 & 6 & High \\
\hline $\begin{array}{l}\text { EGYPTAIR Tourism } \\
\text { \& Duty-Free has } \\
\text { agood reputation and } \\
\text { image }\end{array}$ & 1.3 & 2.6 & 12.7 & 23.7 & 9.2 & 3.74 & 0.914 & 1 & High \\
\hline $\begin{array}{l}\text { You feel safe in your } \\
\text { dealings } \\
\text { EGYPTAIR Tourism }\end{array}$ & 1.8 & 3.9 & 13.2 & 22.4 & 8.3 & 3.64 & 0.973 & 4 & High \\
\hline $\begin{array}{l}\text { EGYPTAIR Tourism } \\
\text { staffs are experienced } \\
\text { and well-trained. }\end{array}$ & 1.3 & 3.5 & 11.4 & 26.8 & 6.6 & 3.68 & 0.889 & 2 & High \\
\hline \begin{tabular}{l} 
Total mean \\
\hline
\end{tabular}
\end{tabular}

Table (11) shows the responses of the study sample that related to the Assurance dimension, where the means ranged between (3.74- 3.60) compared with the total instrument mean for the domain (3.65) the item "EGYPTAIR Tourism \& Duty-Free has agood reputation and image" ranked first with a mean and standard deviation (mean=3.74, standard deviation $=0.914)$ compared with the total instrument mean and the standard deviation. The item "EGYPTAIR Tourism employees are always committed with you" ranked last reached a mean (3.60) and the standard deviation was (0.872) compared with the mean and standard deviation of the total instrument. 
Minia Journal of Tourism and Hospitality Research Vol. (8), No. (1), December 2019

Table (12) Empathy dimension of Hajj and omrah

\begin{tabular}{|c|c|c|c|c|c|c|c|c|c|}
\hline Variables & SD & D & $\mathbf{N}$ & $\mathbf{A}$ & $\mathbf{S A}$ & $\begin{array}{c}\text { Mea } \\
\text { n }\end{array}$ & $\begin{array}{c}\text { Standar } \\
\text { d } \\
\text { deviatio } \\
\text { n } \\
\end{array}$ & $\begin{array}{c}\operatorname{Ran} \\
\mathbf{k}\end{array}$ & Attitude \\
\hline \multicolumn{10}{|l|}{ 5. Empathy } \\
\hline $\begin{array}{l}\text { EGYPTAIR } \\
\text { Tourism staff have } \\
\text { gaven you } \\
\text { individual attention }\end{array}$ & 1.8 & 2.6 & 15.8 & 23.7 & 5.7 & 3.58 & 0.894 & 3 & High \\
\hline $\begin{array}{l}\text { EGYPTAIR } \\
\text { Tourism staff } \\
\text { understands your } \\
\text { specific needs }\end{array}$ & .4 & 3.5 & 16.7 & 24.1 & 4.8 & 3.59 & 0.798 & 2 & High \\
\hline $\begin{array}{l}\text { EGYPTAIR } \\
\text { Tourism takes } \\
\text { consumer's } \\
\text { opinions seriously }\end{array}$ & 1.3 & 4.4 & 16.7 & 21.9 & 5.3 & 3.51 & 0.898 & 5 & High \\
\hline $\begin{array}{l}\text { Passengers are } \\
\text { sufficiently } \\
\text { compensated by } \\
\text { the airline for any } \\
\text { damages that arise } \\
\text { in the shortest } \\
\text { possible time }\end{array}$ & 3.1 & 4.4 & 17.5 & 20.2 & 4.4 & 3.37 & 0.984 & 6 & High \\
\hline $\begin{array}{l}\text { EGYPTAIR } \\
\text { Tourism staff are } \\
\text { show Empathy }\end{array}$ & 1.8 & 3.1 & 16.2 & 22.8 & 5.7 & 3.56 & 0.906 & 4 & High \\
\hline $\begin{array}{l}\text { EGYPTAIR } \\
\text { Tourism staff } \\
\text { provides personal } \\
\text { care equally to } \\
\text { everyone. } \\
\end{array}$ & 1.8 & 2.6 & 14.5 & 21.5 & 8.3 & 3.66 & 0.949 & 1 & High \\
\hline \multicolumn{6}{|l|}{ Total mean } & 3.54 & & & \\
\hline
\end{tabular}

Table (12) shows the responses of the study sample that related to the Empathy dimension ,where the means ranged between (3.663.37) compared with the total instrument mean for the domain (3.54) the item "EGYPTAIR Tourism staff provides personal care equally to everyone" ranked first with a mean and standard deviation (mean=3.66, standard deviation $=0.949$ ) compared with the total instrument mean and the standard deviation. The item "Passengers 
are sufficiently compensated by the airline for any damages that arise in the shortest possible time" ranked last reached a mean (3.37) and the standard deviation was (0.984) compared with the mean and standard deviation of the total instrument.

Spearman Correlation analyses

Correlation between Passenger Satisfaction and service quality

Table (13) Correlation between Passenger Satisfaction and Hajj \& Omrah service quality

\begin{tabular}{|c|c|c|}
\hline & & hajj \\
\hline \multirow{2}{*}{\begin{tabular}{|l} 
Passenger \\
Satisfaction
\end{tabular}} & Correlation Coefficient & $.790^{* *}$ \\
\hline & Sig. & .000 \\
\hline
\end{tabular}

As seen in the table (13), there is a positive and significant relationship between passenger satisfaction and Hajj \& Omrah service that provided by EGYPTAIR tourism . The value of spearman correlation coefficient was $\left(.790^{* *}-\operatorname{sig}=0.000\right)$. These results showed that there is a strong positive relation between customer satisfaction and Hajj \& Omrah service. This positive correlation indicates that as the passenger satisfaction increases, using of Hajj \& Omrah service increases. This confirms the validity of the hypothesis (H01) that There is a statistically significant relationship between the service quality of Hajj \& Omrah service and customer satisfaction.

Table (14) Correlation between Passenger Satisfaction and Domestic Tours

service quality

\begin{tabular}{|c|c|c|}
\hline & & Domestic \\
\hline \multirow{2}{*}{\begin{tabular}{|l} 
Passenger \\
Satisfaction
\end{tabular}} & Correlation Coefficient & $.792^{* *}$ \\
\hline & Sig. & .000 \\
\hline
\end{tabular}

As seen in the table (14), there is a positive and significant relationship between passenger satisfaction and Domestic Tours service. The value of spearman correlation coefficient was $\left(.792^{* *}-\operatorname{sig}\right.$ $=0.000)$. These results showed that there is a strong positive relation between passenger satisfaction and Domestic Tours service. This positive correlation indicates that as the passenger satisfaction increases, using of Domestic Tours service increases. This confirms 
the validity of the hypothesis (H02) that There is a statistically significant relationship between the Domestic Tours service quality and customer satisfaction.

\section{Conclusion and Recommendations Summary and Conclusion}

This study examines the relationship between the service quality dimensions and customer satisfaction. The study documents a significant positive relationship among all the service quality dimensions consisting of tangible, reliability, responsiveness, assurance and empathy. Likewise, all the dimensions exhibit a positive significant correlation with the service quality. Correspondingly, the relationship between the service quality and its dimensions is significant and positively related to customer satisfaction. On this note, customers' perceptions and the evaluation of the service quality offered by EGYPTAIR tourism and duty-free hinge on the service quality dimensions. This study highlights the significance of understanding customers' needs and expectations as a basis for developing capabilities to maintain loyal customers. The findings of this study further suggest that the service quality improvement initiatives should begin with recognizing the customers' needs.

This research tested a conceptual schema developed based on relevant service quality research literature. The measurement scale used in this study met the acceptable standards of the validity and reliability analyses. confirmed that service quality was significantly correlated with customer satisfaction and customer loyalty, therefore H1 was supported. This finding explains that the capability of EGYPTAIR tourism and duty-free to appropriately implement the service quality dimensions, namely tangible, reliability, responsiveness, assurance, and empathy may enhance customer satisfaction and customer loyalty in the company.

Future research should seek to examine the use of SERVQUAL to close other service quality gaps for different types of companies. In this paper, service quality and its model of gaps were reviewed. SERVQUAL methodology as an analytical approach for evaluating the difference between customers' expectations and perceptions of quality was also studied. While this research provides some perspectives to the field of service quality, The results of the current 
study illustrate that company can at least assess five dimensions of service quality to ascertain the level of services provided and to determine which dimensions need improvement. In order to improve service quality, it is necessary to contact employees regularly and assess their service experiences. Like the external customer, an internal customer too considers categories of service attributes, such as reliability and responsiveness, in judging the quality of the service.

develop a better understanding of the relationship between the service quality that provided by EGYPTAIR tourism and duty-free and customer satisfaction, This research used the descriptive-analytical approach, where a questionnaire was prepared and distributed to a random sample of (255) of customers. From the original sample, 228 questionnaires were used, representing $89.5 \%$ response rate.

The major purpose of this study was to Measur the services quality that provided by EGYPTAIR Tourism and Duty Free and its impact on customer satisfaction. This research evaluates the impact of the services quality that provided by EGYPTAIR tourism and Duty Free on customer satisfaction. Different tests were applied, including reliability test, Frequencies, Percentages, Means, and Standard Deviation, correlation test, and regression test. The following results were obtained.

- The results of the study showed the reliability of the questionnaire by calculating the Cronbach's Alpha Value. The tests showed that the Reliability Coefficients for all the sections were equal .996 and Validity Coefficient for all the sections were equal .997 which indicates that the instrument is reliable for being used.

- Totally, it was seen that $\% 53$ customers were male and Most of the respondents $44.7 \%$ were aged between 18 and 28 years. Regarding the education level, $68 \%$ of the respondents were studying for Bachelor's degrees. Additionally, more than 35.5 $\%$ of the respondents reported an income range between 3.000and 5.999 EGP. Regarding the purpose of their journeys, about $86.8 \%$ mentioned that they were traveling for Entertainment / Vacation.the majority (54.4\%) of the sample travel for a purpose Tourist programs inside Egypt By Egypt Air Tourism \& Duty-Free, (50\%) of the sample travel from 1 to 2 by Egypt Air Tourism \& Duty-Free in the past 12 months, whereas( (78.5\%) of the sample use Company website to get information about EGYPTAIR Tourism and Duty-Free. 
- The results of the study indicated a strong positive correlation between the dimensions of service quality (tangible, reliability, responsiveness, assurance and empathy) and customer satisfaction. It can be concluded from this that EGYPTAIR tourism 's customer satisfaction can be increased by improving the service quality of in all its dimensions.

\section{Services offered by EgyptAir Tourism And Duty Free:}

1- The findings from the distributed questionnaires revealed that The highest mean values for assessing Hajj and omrah programs emerged for the item"The staff looks neat and tidy" ranked first with a mean and standard deviation $($ mean $=3.77$, standard deviation $=0.973)$. The item"EGYPTAIR Tourism \& Duty-Free is a wellrepresented and reputable company" ranked second with a mean and standard deviation (mean $=3.74$, standard deviation $=0.914$ ).

2- The findings from the distributed questionnaires revealed that The highest mean values for assessing Tourist programs inside Egypt emerged for the item "You feel secure in your dealings with EGYPTAIR tourism and duty free" ranked first with a mean and standard deviation (mean $=3.74$, standard deviation $=0.986$ ). The item"EGYPTAIR tourism and duty free renders its services accurately and in due time" ranked second with a mean and standard deviation (mean $=3.71$, standard deviation $=0.966$ ).

3- The findings from the distributed questionnaires revealed that The highest mean values for assessing Tourist programs outside Egypt emerged for the item "EGYPTAIR Tourism staff is prepared to assist you" ranked first with a mean and standard deviation (mean=4.18, standard deviation $=5.012$ ). The item"EGYPTAIR Tourism staff renders quick and immediate services to Customers" ranked second with a mean and standard deviation (mean $=3.76$, standard deviation $=0.863$ ).

4- The findings from the distributed questionnaires revealed that The highest mean values for assessing 
Transit servicing emerged for the item "EGYPTAIR Tourism staff renders quick and immediate services to Customers" ranked first with a mean and standard deviation $($ mean $=3.52$, standard deviation $=0.873)$. The item"EGYPTAIR Tourism staff is always committed to you" ranked second with a mean and standard deviation $($ mean $=3.45$, standard deviation $=0.941)$.

5- The findings from the distributed questionnaires revealed that The highest mean values for assessing Meetings \& conferences organizing service emerged for the item "Passengers shall be adequately compensated by the airline for any damages arising in the shortest possible time" ranked first with a mean and standard deviation (mean $=4.15$, standard deviation $=5.356)$. The item"EGYPTAIR Tourism renders good-quality services that fulfill Customer 's needs" ranked second with a mean and standard deviation $($ mean $=3.56$, standard deviation $=$ $0.970)$.

6-The findings from the distributed questionnaires revealed that The highest mean values for assessing Transportation services emerged for the item "The waiting period for rendering the service is short" ranked first with a mean and standard deviation (mean $=3.57$, standard deviation $=0.920$ ). The item"Quickness of response to complaints and solving problems" ranked second with a mean and standard deviation (mean $=3.55$, standard deviation $=0.958$ ) .

7- The findings from the distributed questionnaires revealed that The highest mean values for assessing Online booking services emerged for the item "EGYPTAIR Tourism staff provides you with accurate answers to your inquiries" ranked first with a mean and standard deviation (mean $=3.85$, standard deviation $=$ 3.883). The item"EGYPTAIR Tourism staff takes consumer's opinions seriously" ranked second with a mean and standard deviation (mean $=4.16$, standard deviation $=5.22$ ) .

8- The findings from the distributed questionnaires revealed that The highest mean values for assessing DutyFree

emerged for the item "The staff looks neat and tidy" ranked first with a mean and standard deviation 
(mean $=3.55$, standard deviation $=0.909$ ). The item"EGYPTAIR Tourism staff are show Empathy" ranked second with a mean and standard deviation $($ mean $=3.54$, standard deviation $=0.943)$.

Results showed that there is positive significant relationship between customer satisfaction and service qualityof EGYPTAIR tourism and duty free. The value of spearman correlation coefficient was $(.717 * *$ $-\operatorname{sig}=0.000)$.

\section{$\underline{\text { Recommendations }}$}

$\underline{\text { Recommendations for EGYPTAIR torism and duty free }}$

According to the results obtained from the theoretical framework of the study as well as the results achieved.Obtained from the statistical analysis of the data, the following recommendations were made:

- Egypt Air Tourism \& Duty Free should develop its services with high quality at a reasonable price in order to help the company to compete and maintain customers.

- EGYPTAIR for Tourism and Duty Free should seek to improve high quality levels through attention to all dimensions of quality (tangibility, reliability, reliability, responsiveness, empathy), and the study also stressed the urgent need for attention to these dimensions.In addition to the price and image of company

- EGYPTAIR Tourism and Duty Free Shops should pay great attention to customer satisfaction by choosing skilled workers on how to provide service and gain customer satisfaction by either introducing them or designing a training program for them to acquire the knowledge and skills required to provide services

- Egypt Air should recognize the changing requirements and expectations of passengers

- Possibility to follow up and practice modern equipment and equipment in use Full restructuring of the company, staff training, low prices and punctuality Low prices and rapid response to requests and respond to complaints Commitment as much as possible and maintain a decent appearance and respect the deadlines Regularity of appointments 
- Egyptair should must diversity in programs and diversity in offers in order to help the client to reach his wishes and requirements.

- $\quad$ EgyptAir should increase interest in transit service and provide better service to passengers through offers, discounts, and personalized services that support build a trusted relationship,carries out its programs from the first time, When the client encounters a problem he manifests genuine interest in solving it and Quickness of response to complaints and solving problems

- Egypt Air Tourism \& Duty Free should develop Online booking services,renders its services accurately and in due time, When the client encounters a problem he manifests genuine interest in solving it,Quickness of response to complaints and solving problems, The waiting period for rendering the service is short

- The research thus recommended Egypt Air Tourism \& Duty Free should develop its services with high quality at a reasonable price in order to help the company to compete and maintain customers

\section{$\underline{\text { References }}$}

- Ahmad, B. S. (2007), Evaluating an extended relationship marketing model for Arab guests of Five-Star hotels. Ph. D. Thesis, School of Hospitality, Tourism and Marketing, Faculty of Business and Law, Victoria University, Melbourne, available at: http://www.vuir.vu.edu.au/511/shammout.ped, accessed:29 feb 19.

- Ary, D., Jacobs, L. and Razavieh, A. (2002). "Introduction to Research in Education", Belmont, CA: Wadsworth/Thomson.

- Baker, D. M. A. (2012). Service quality and customer satisfaction in the airline industry: A comparison between legacy airlines and low-cost airlines. American Journal of Tourism Research, 2(1).

- Blodgett, J.G., Wakefield, K.L., \& Barnes, J.H. (1995). The effects of Customer Service on Consumer Complaining Behavior. Journal of Services Marketing, 9(4).

- Boshoff, C., \& Gray, B. (2004). The relationship between service quality, customer satisfaction and buying intentions in the private hospital industry. South African Journal of Busines Management ,35(4), 27-37. 
- Chen, Y. K., Chen, C. Y., \& Hsieh, T. F. (2007). Correlation of service quality, customer satisfaction, customer loyalty and life style at hotel springs hotels. Journal of International Management Studies, 2(2), 51-59.

- Chidambaram, V, \& Ramachandran, A, (2012), A review of customer satisfaction towards service quality of banking sector. Social and Management Sciences, V2(2), 71-79.

- Chitty, B., Ward, S., \& Chua, C. (2007). An application of the ECSI model as a predictor of satisfaction and loyalty for backpacker hostels. Marketing Intelligence \& Planning, 25, 563.

- Egan, J. (2004). Relationship marketing: Exploring relational strategies in marketing. Harlow: Pearson Education Ltd.

- Falk, T., Hammerschidt, M., \& Schepers, J. J. L. (2010). The service quality-satisfaction link revisited: Exploring asymmetries and dynamics. Journal of the Academy of Marketing Science, 38,288-302.

- Gerson, R., 1993. Measuring Customers' Satisfaction: a Guide to Managing Quality Service. Crisp Publications, CA

- He, Y., \& Song, H. (2009). A mediation model of tourists' repurchase intentions for packaged tour services. Journal of Travel Research, 47(3), 317-331.

- Hu, H., Kandampully, J., \& Juwaheer, D. (2009). Relationships and impacts of service quality,perceived value, customer satisfaction, and image: an empirical study. Service Industries Journal, 29(2), 111-125.

- Hza, D, (2011), Air transport, P. 43:206

- Jaiswal, A.K. and Niraj, R. (2011), "Examining mediating role of attitudinal loyalty and nonlinear effects in satisfactionbehavioral intentions relationship", Journal of Services Marketing,Vol. 25 No. 3, pp. 165-175.

- Jen W, Tu R, Lu T. (2011) Managing passenger behavioral intention: an integrated framework for service quality, satisfaction, perceived value, and switching barriers. Transportation, 38, 321-342.

- Kenan, A., \& Yıldırım, S. (2012). The measurement of service quality with servqual for different domestic airline firms in Turkey. Serbian Journal of Management, 7(2).

- Kim, Y.K. \& Lee, H.R. (2011). Customer satisfaction using low cost carriers. Tourism Management. 32(2), 235-243 
- Lewis A (2010). Service quality model evaluation. Journal of Transport Logistic Management International Review 34: 235254.

- Mishal, M. (2015), " Evaluation of AIRQUAL" scale for measuring airline service quality and its effect on customer satisfaction and loyalty", $\mathrm{PhD}$ Thesis of Transport and Manufacturing Centre for Air Transport Management, Cranfield University, London, united kingdom.

- Munusamy, J., Chelliah, S., 2011. An investigation of impact of service strategy on customers' satisfaction in the budget airline industry in Malaysia: a case study of air Asia. Contemp. Mark. Rev. 1 (1), 1e13

- Namukasa, J. 2013. "The influence of airline service quality on passenger satisfaction and loyalty: The case of Uganda airline industry." The TQM Journal 25 (5): 520-532.

- Oliver, Richard L, 1997. Satisfaction : A Behavioral Perspective on the Consumer. Singapore : McGraw-Hill Companies Inc.

- Parasuraman A, Zeithaml VA, Berry LL (1985). SERVQUAL: A multipleitem scale for measuring customer perceptions of service quality. J.Retail. 64(1):12-40.

- Parasuraman, A., Berry, L, \& Zeithaml, V. (1988). SERVQUAL: A multiple-item scale for measuring customer perceptions of service quality. Journal of Retailing, 64, 26-43.

- Parasuraman, A., Zeithaml, V.A., and Berry, L.L. (1985). A conceptual model of service quality and its implications for future research. Journal of Marketing, 49(4), 41-50.

- Park, J. W., Robertson, R. and Wu, C.-L. (2005), "Investigating the effects of service qualityon airline image and behavioural intentions: Findings from Australian international air passengers", Journal of Tourism Studies, Vol. 16 No. 1, pp. 2-11.

- Rahim, A. G. (2015). Customer satisfaction and loyalty towards perceived service quality of domestic airlines in Nigeria. Doctoral Thesis. Lagos, Nigeria: University of Lagos.

- Roberts, K., Varki, S., \& Brodie, R. (2003). Measuring the quality of relationships in consumer services: An empirical study. European Journal of Marketing, 37(1/2), 169-196.

- Roy, S.K., Lassar, W.M., Ganguli, S., Nguyen, B. \& Yu, X. (2015). Measuring service quality: A systematic review of 
literature, International Journal Services, Economics and Management, 7(1), 24-52

- Saha, G.C. and Theingi (2009). Service Quality, Satisfaction, and Behavioural Intentions: A Study of Low-cost Airline Carriers in Thailand. Managing Service Quality, Vol. 19 No. 3, pp. 350-372.

- Seth, N., Deshmukh, S. G., \& Vrat, P. (2005). Service quality models: a review. International Journal of Quality \& Reliability Management, 22(9), 913-949

- Silvia, F., Pedro, F., Vitor, C., \& Jael, A. (2013). Satisfaction, commitment and loyalty in online and offline retail in Portugal. European Journal of Business and Social Sciences, 2(7), 49-66

- Sousa, R. \& Voss, C. 2009. "The effects of service failure and recovery on customer loyalty in e-services: An empirical investigation." International Journal of Operations and Production management 29 (8): 834-64

- Tsoukatos, E., and Mastrojianni, E., (2010), "Key determinants of service quality in retail banking", EuroMed Journal of Business, Vol. 5 No.1, pp. 85-100.

- Yuksel, A., Yuksel, F. and Bilim, Y. (2010), "Destination attachment: effects on customer satisfaction and cognitive, affective and conative loyalty", Tourism Management, Vol. 31No. 2, pp. 274-284 .

- Zahari, W., Yusoff, W., \& Ismail, M. (2008). FMSERVQUAL: a new approach of service quality measurement framework in local authorities. Journal of Corporate Real Estate, 10(2),130-144.

- Zeithaml, V. A., Berry, L. L., \& Parasuraman, A. (1996). The behavioral consequences of service quality. Journal of Marketing, 60(may), 31-46

- Zineldin, M. (2006). The royalty of loyalty: CRM, quality and retention. Journal of Consumer Marketing, 23(7), 430-437.

\section{$\underline{\text { Internet Websites }}$}

- EGYPTAIR (2019), " EGYPTAIR (Karnak)" , Available online: http://karnak.EGYPTAIR.com/en/packagespackages_categories/page/106,Accessed on February 5,2019 (01:00Am).

- EGYPTAIR (2019) , " About EGYPTAIR", Available online https://www.egyptair.com/en/about- 
Minia Journal of Tourism and Hospitality Research Vol. (8), No. (1), December 2019

egyptair/Pages/egyptair-group.aspx , Accessed on February 5,2019 (03:00Am).

- EGYPTAIR (2019) , " EGYPTAIR Annual Report", 2016/2017 " , Available online: http://www.EGYPTAIR.com , Accessed on February 5,2019 (02:00Am).

- EGYPTAIR. (2019) " EGYPTAIR Annual Report, 2010/2011 " , Available online: http://www.EGYPTAIR.com ¿Accessed on February 5,2019 (02:00Am).

- EGYPTAIR. (2019) , " EGYPTAIR Annual Report, 2017/2018 " , Available online: http://www.EGYPTAIR.com , Accessed on September 25,2019 (10:00am). 
Minia Journal of Tourism and Hospitality Research Vol. (8), No. (1), December 2019 